\title{
Clinicopathological significance of SMAD4 loss in pancreatic ductal adenocarcinomas: a systematic review and meta-analysis
}

\author{
Jin-Dao Wang ${ }^{1, *}$, Ketao Jin ${ }^{1,}$, , Xiao-Ying Chen ${ }^{2}$, Jie-Qing Lv ${ }^{1}$, Ke-Wei Ji ${ }^{1}$ \\ ${ }^{1}$ Department of Gastrointestinal Surgery, Shaoxing People's Hospital, Shaoxing Hospital of Zhejiang University, Shaoxing \\ City, Zhejiang Province, China \\ ${ }^{2}$ Psychosomatic Second Division, Shaoxing 7th People's Hospital, Shaoxing City, Zhejiang Province, China \\ *These authors have contributed equally to this work \\ Correspondence to: Ke-Wei Ji, email: jieqing.l@yahoo.com
}

Keywords: PDAC, SMAD4, DPC4, diagnosis, prognosis

Received: September 06, 2016

Accepted: November 08, 2016

Published: December 28, 2016

\section{ABSTRACT}

Pancreatic ductal adenocarcinoma (PDAC) is one of the leading causes of cancer mortality. Although advances have been made in understanding the pathogenesis of PDAC, the outcome still remains poor. The aim of this study is to conduct a metaanalysis to evaluate the precise association between SMAD4 loss and clinicopathological significance in PDAC. A literature search was made in PubMed, Web of Science, Google scholar, and EMBASE for related publications. The data were extracted and assessed by two reviewers independently. Analysis of pooled data was performed, Odds Ratio or Hazard Ratio with corresponding confidence intervals was calculated and summarized. 12 relevant articles were included for full review in detail and metaanalysis. The frequency of SMAD4 protein loss was significantly increased in PDAC than in nonmalignant pancreatic tissue, Odd Ratio was 0.05 with $95 \%$ confidence interval $0.01-0.23, p<0.0001$. SMAD4 loss was significantly associated with poor overall survival in patients with PDAC, Hazard Ratio was 0.61 with $95 \%$ confidence interval 0.38 $0.99, p=0.05$. SMAD4 loss was not correlated with the size, grades, and lymph node metastasis of PDAC. In conclusion, SMAD4 is a biomarker for the diagnosis of PDAC. SMAD4 loss is significantly related to poor prognosis in patients with PDAC.

\section{INTRODUCTION}

Pancreatic ductal adenocarcinoma (PDAC) is one of the leading causes of cancer mortality. Although improvement in clinical management has been made last two decades, the prognosis of PDAC remains poor, and a 5 -year survival rate is approximately $5 \%[1-3]$. Because of a lack of specific symptoms and appropriate markers for early stages, most PDAC patients are diagnosed at advanced stages, when radical pancreatic resection is not possible. Therefore, it is critical to identify biomarkers for early diagnosis and development of gene targeted therapy. SMAD4 was also known as the deleted in pancreatic carcinoma 4 (DPC4), is located on chromosome 18q21 [4-5]. SMAD4 is a co-factor that facilitates gene transcription and tumor suppression through the TGF-beta signaling pathway. TGF-beta/SMAD4 signaling pathway regulates tumor development through mediating growth arrest and inducing apoptosis [5-11]. Previous studies have attempted to correlate the alteration of SMAD4 with clinical features and prognosis in patients with PDAC [12-15]. However, a clear correlation has not been established. We conducted a meta-analysis to investigate the association of SMAD4 status with clinicopathlogical significance and prognosis in patients with PDAC.

\section{RESULTS}

12 studies were included for meta-analysis (Figure 1). The main characteristics were listed in Table 1.

The rate of SMAD4 protein loss was significantly higher in PDCA than in nonmalignant pancreatic tissue (including normal pancreas and hyperplasia), OR was 0.05 with $95 \%$ CI $0.01-0.23, \mathrm{z}=3.97, \mathrm{p}<0.0001, I^{2}=0 \%$ (Figure 2). The frequency of SMAD4 protein loss was similar between high and low grade of PDCA, OR was 0.92 with $95 \%$ CI $0.41-2.05, \mathrm{z}=0.20, \mathrm{p}=0.84, I^{2}=61 \%$ (Figure 3). Loss of SMAD4 protein was not associated with lymph node metastasis status, OR was 0.71 with $95 \%$ CI $0.42-1.21, \mathrm{z}=1.25, \mathrm{p}=0.21, l^{2}=57 \%$ (Figure 4). There 
was no significantly difference of SMAD4 protein loss rate between large and small size of PDCA tumor, OR was 0.94 with $95 \%$ CI $0.70-1.25, \mathrm{z}=0.42, \mathrm{p}=0.68, I^{2}=0 \%$ (Figure 5). Loss of SMAD4 protein was significantly correlated to overall survival in patients with PDCA, HR was 0.61 with $95 \%$ CI $0.38-0.99, \mathrm{z}=1.99, \mathrm{p}=0.05, I^{2}=67 \%$ (Figure 6).

The methodological quality of each study was assessed separately and independently by JW and XC using Newcastle Ottawa Quality Assessment Scale (NOQAS). This scale for non-randomized case controlled studies and cohort studies was used to allocate a maximum of nine points for the quality of selection, comparability, exposure, and outcomes for study participants. Among 12 studies, two scored 6, six scored 7, and four scored 8. Therefore, the studies were relatively high quality (Table 2). A sensitivity analysis, in which one study was removed at a time, was conducted to assess the result stability. The pooled ORs and HR were not significantly changed, suggesting the stability of our analyses. The funnel plots showed largely symmetric (Figure 7) which indicated there was no publication biases in the meta-analysis of SMAD4 protein expression and clinicopathological features.

\section{DISCUSSION}

Although tremendous progress has been made last two decades in understanding the pathogenesis of PDAC, five-year survival rates are still less than 5\% [7]. The development and progression of PDAC involve various gene alterations including oncogene activation and loss of tumor suppressor gene function [16-18]. The understanding of molecular biology in PDAC contributes to the development of new approaches to its prevention, diagnosis and treatment. Previous studies investigated the relationship of loss of SMAD4 with the features of PDAC and its prognosis in patients, however, the correlation was not clear due to small power of the samples [12-13, 19].

Our data showed the loss of SMAD4 protein expression was significantly increased in PDAC than nonmalignant pancreatic tissues. TGF-beta/SMAD4 signaling regulates tumor development because of its effects on growth arrest and induced apoptosis [5, 8-9].

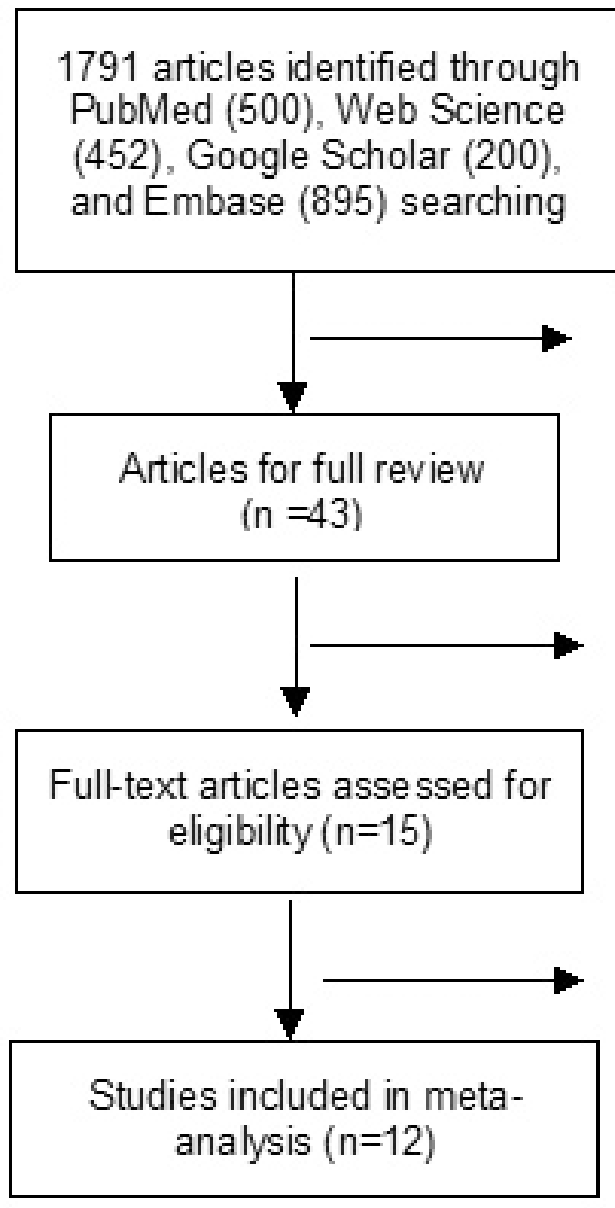

\section{Articles excluded on screening of titles and/or abstracts $(n=2004)$}
Articles excluded for not present the usable data $(n=28)$

\section{Full-text articles excluded, due to study involving SMAD4 gene expression $(n=3)$}

Figure 1: Schematic flow diagram for selection of included studies. 
Table 1: Main Characteristics of included studies

\begin{tabular}{|c|c|c|c|c|c|c|c|c|c|c|}
\hline Author & Year & Country & Sample & Patient age & $\begin{array}{c}\text { Grade } \\
(\mathrm{L} / \mathrm{H})\end{array}$ & $\begin{array}{c}\text { Size } \\
(<\mathbf{3 0} />\mathbf{3 0})\end{array}$ & $\begin{array}{c}\text { LN status } \\
(-/+)\end{array}$ & $\begin{array}{c}\text { Follow- } \\
\text { up(median) }\end{array}$ & IHC staining & $\begin{array}{c}\text { SMAD4 } \\
\text { Ab }\end{array}$ \\
\hline Bachet [13] & 2012 & France & 471 & Median 63 & $335 / 51$ & $225 / 161$ & $25 / 291$ & $26 \mathrm{MO}$ & nuclear & $\begin{array}{c}\text { Santa Cruz } \\
1: 100\end{array}$ \\
\hline Biankin [38] & 2002 & Australia & 348 & Median 67 & $38 / 13$ & & $27 / 24$ & $3.5 \mathrm{MO}$ & cytoplasma & Santa Cruz \\
\hline Javle [39] & 2014 & USA & 91 & Mean 60.6 & $40 / 20$ & & & & nuclear & $\begin{array}{l}\text { Proteintech } \\
\text { Group, } \\
\text { Inc. } 1: 450\end{array}$ \\
\hline $\begin{array}{l}\text { Handra- } \\
\text { Luca [12] }\end{array}$ & 2013 & France & 99 & $\begin{array}{c}\text { Median } \\
\text { age, Women } \\
\text { 61, Men } 63.5\end{array}$ & $62 / 29$ & $34 / 57$ & $15 / 76$ & $26 \mathrm{MO}$ & nuclear & $\begin{array}{c}\text { Santa Cruz } \\
1: 100\end{array}$ \\
\hline Hua [19] & 2003 & China & 34 & Median 55 & $27 / 7$ & & $20 / 14$ & & $\begin{array}{l}\text { nuclear and / } \\
\text { or cytoplasma }\end{array}$ & $\begin{array}{c}\text { Santa Cruz } \\
1: 100\end{array}$ \\
\hline Oshima [29] & 2013 & Japan & 106 & Median 69.5 & $91 / 15$ & & $34 / 72$ & & $\begin{array}{c}\text { nuclear and / } \\
\text { or cytoplasma }\end{array}$ & $\begin{array}{c}\text { Santa Cruz } \\
1: 100\end{array}$ \\
\hline $\begin{array}{l}\text { Ottenhof } \\
{[40]}\end{array}$ & 2012 & Netherlands & 78 & Mean 63 & $61 / 16$ & & $23 / 54$ & $27 \mathrm{MO}$ & nuclear & $\begin{array}{c}\text { Santa Cruz } \\
1: 300\end{array}$ \\
\hline Tang [41] & 2002 & China & 25 & & & & & & & \\
\hline Tascilar [28] & 2001 & USA & 249 & $\begin{array}{c}\text { Mean } \\
65.4 \pm 10.5\end{array}$ & & $168 / 141$ & $93 / 156$ & $17 \mathrm{MO}$ & $\begin{array}{l}\text { nuclear and / } \\
\text { or cytoplasma }\end{array}$ & $\begin{array}{c}\text { Santa Cruz } \\
1: 100\end{array}$ \\
\hline Toga [42] & 2004 & Japan & 88 & $\begin{array}{c}\text { Mean } \\
65.9 \pm 9.5\end{array}$ & $82 / 6$ & & $10 / 78$ & & nuclear & $\begin{array}{c}\text { Santa Cruz } \\
1: 100\end{array}$ \\
\hline Xiang [43] & 2016 & China & 241 & Median 62 & & & $112 / 129$ & $18.5 \mathrm{MO}$ & & $\begin{array}{c}\text { Abcam } \\
1: 150\end{array}$ \\
\hline Zhang [44] & 2006 & China & 30 & & $24 / 6$ & & & & & \\
\hline
\end{tabular}

L: Low, H: High; LN: Lymph Node; Ab:antibody; MO: month; IHC: Immunohistochemistry

Mitogenic growth signals, which are regulated by TGFbeta/SMAD4, are required during the process of cell cycle $[8,20]$. Therefore, SMAD4 functions as a tumorsuppressor through growth arrest during tumorgenesis. Previous study indicated that TGF-beta could affect growth arrest through upregulating p21 in a SMAD4dependent manner in colon cancer [21]. Additionally, TIEG, a Zinc-finger encoding gene regulated by TGFbeta/SMAD4 signaling was reported to induce apoptosis in pancreatic cells (PCs) [22]. Moreover, SMAD4 downregulation caused TGF-beta-induced cell cycle arrest and apoptosis, and the restoration of SMAD4 by gene therapy reversed the invasive phenotype as well as reduced the proliferation in PC cell lines [23-25]. An increase in G1 phase fraction was observed in a PDAC cell lines after inducing SMAD4 expression through a tetracycline system construct. The frequency of SMAD4 protein loss was similar between different sizes as well as different grades of PDAC. More studies are needed to confirm the correlation between SMAD4 status and PDAC features. A

\begin{tabular}{|c|c|c|c|c|c|c|c|c|}
\hline Study or Subgroup & $\begin{array}{r}\text { PDA } \\
\text { Events }\end{array}$ & Total & \multicolumn{2}{|c|}{ Nonmalignant Tissue } & Weight & $\begin{array}{c}\text { Odds Ratio } \\
\text { M-H, Fixed, } 95 \% \mathrm{CI}\end{array}$ & \multicolumn{2}{|c|}{$\begin{array}{c}\text { Odds Ratio } \\
\text { M-H, Fixed, } 95 \% \mathrm{Cl}\end{array}$} \\
\hline Hua 2003 & 26 & 34 & 16 & 16 & $19.5 \%$ & $0.09[0.01,1.75]$ & 4 & - \\
\hline Tang 2002 & 12 & 25 & 35 & 35 & $56.0 \%$ & $0.01[0.00,0.24]$ & & \\
\hline Zhang 2006 & 15 & 30 & 9 & 10 & $24.5 \%$ & $0.11[0.01,0.99]$ & & \\
\hline Total $(95 \% \mathrm{Cl})$ & & 89 & & 61 & $100.0 \%$ & $0.05[0.01,0.23]$ & & \\
\hline Total events & 53 & & 60 & & & & & \\
\hline $\begin{array}{l}\text { Heterogeneity. Chi }{ }^{2}= \\
\text { Test for overall effect }\end{array}$ & $\begin{array}{l}1.49, d f= \\
Z=3.97\end{array}$ & $\begin{array}{l}2(P= \\
P<0.0\end{array}$ & $\begin{array}{l}0.47) ;\left.\right|^{2}=0 \% \\
0001)\end{array}$ & & & & $0.01 \quad 0.1 \quad 1$ & \begin{tabular}{cc|}
10 & 100 \\
Nonmalianant Tiss
\end{tabular} \\
\hline
\end{tabular}

Figure 2: Forest plot for SMAD4 protein expression in PDAC and nonmalignant pancreatic tissue. 


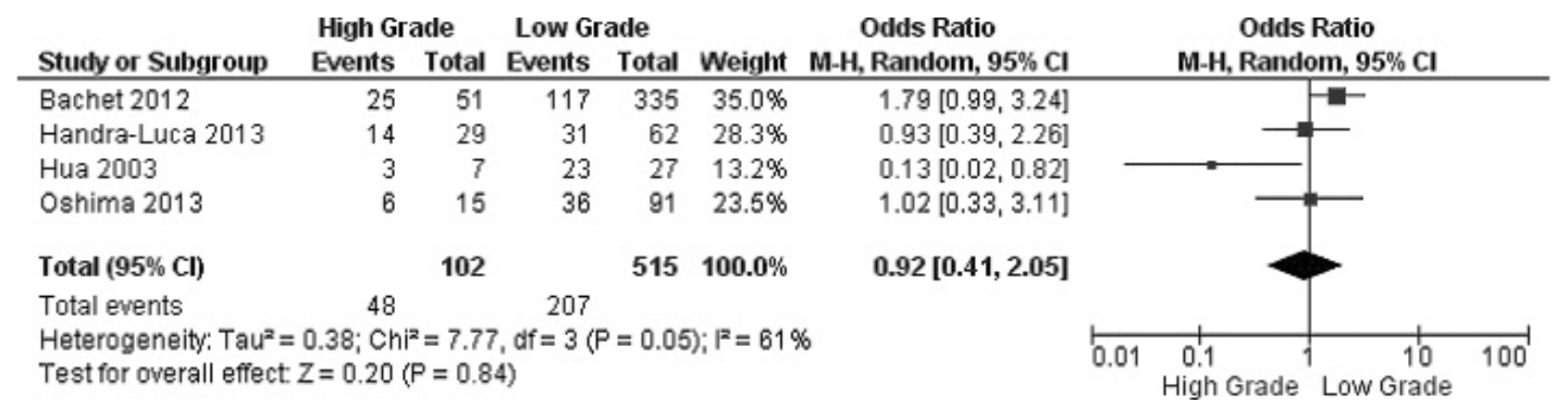

Figure 3: Forest plot for SMAD4 protein expression in different grade of PDAC.

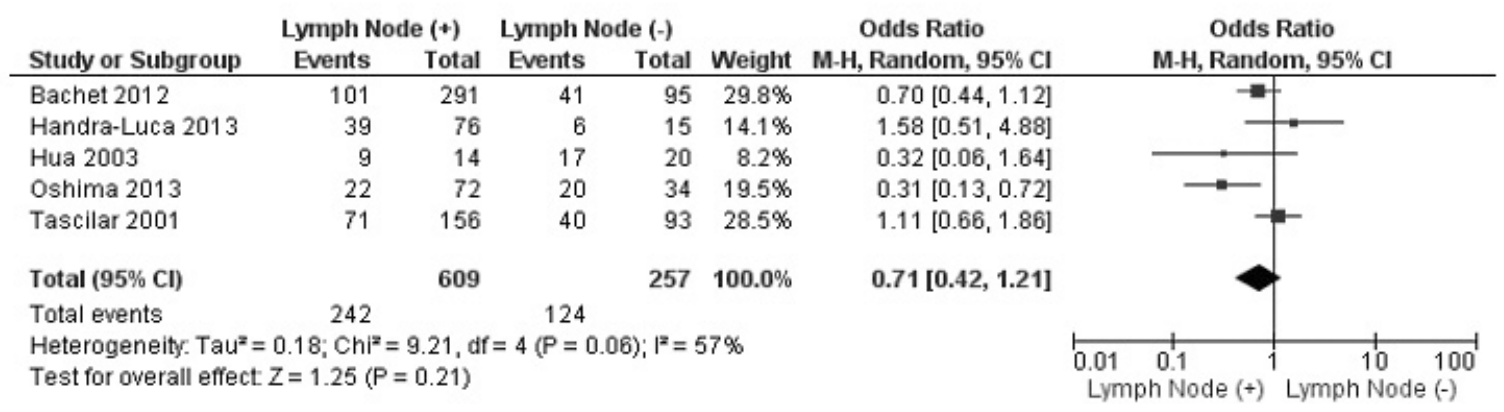

Figure 4: Forest plot for SMAD4 protein expression in different lymph node metastasis status.

\begin{tabular}{|c|c|c|c|c|c|c|c|c|c|}
\hline Study or Subgroup & \multicolumn{2}{|c|}{$>30 \mathrm{~mm}$} & \multicolumn{2}{|c|}{$<30 \mathrm{~mm}$} & Weight & $\begin{array}{c}\text { Odds Ratio } \\
\text { M-H, Fixed, 95\% Cl }\end{array}$ & \multicolumn{2}{|r|}{$\begin{array}{c}\text { Odds Ratio } \\
\text { M-H, Fixed, 95\% Cl }\end{array}$} & \\
\hline Bachet 2012 & 59 & 161 & 83 & 225 & $46.1 \%$ & $0.99[0.65,1.51]$ & & & \\
\hline Handra-Luca 2013 & 29 & 57 & 16 & 34 & $10.4 \%$ & $1.17[0.50,2.73]$ & & & \\
\hline Tascilar 2001 & 60 & 141 & 79 & 168 & $43.5 \%$ & $0.83[0.53,1.31]$ & & & \\
\hline Total $(95 \% \mathrm{Cl})$ & & 359 & & 427 & $100.0 \%$ & $0.94[0.70,1.25]$ & & & \\
\hline Total events & 148 & & 178 & & & & & & \\
\hline $\begin{array}{l}\text { Heterogeneity. } \mathrm{Chi}^{2} \text { = } \\
\text { Test for overall effect }\end{array}$ & $\begin{array}{l}0.57, d f= \\
Z=0.42\end{array}$ & $\begin{array}{l}2(P=0 \\
P=0.68\end{array}$ & $\begin{array}{l}0.75) ;\left.\right|^{2}= \\
8)\end{array}$ & $0 \%$ & & & 0.01 & ${ }^{0.1}{ }^{1} \mathrm{~mm}^{1} 30 \mathrm{~mm}^{10}$ & 100 \\
\hline
\end{tabular}

Figure 5: Forest plot for SMAD4 protein expression in different size of PDAC.

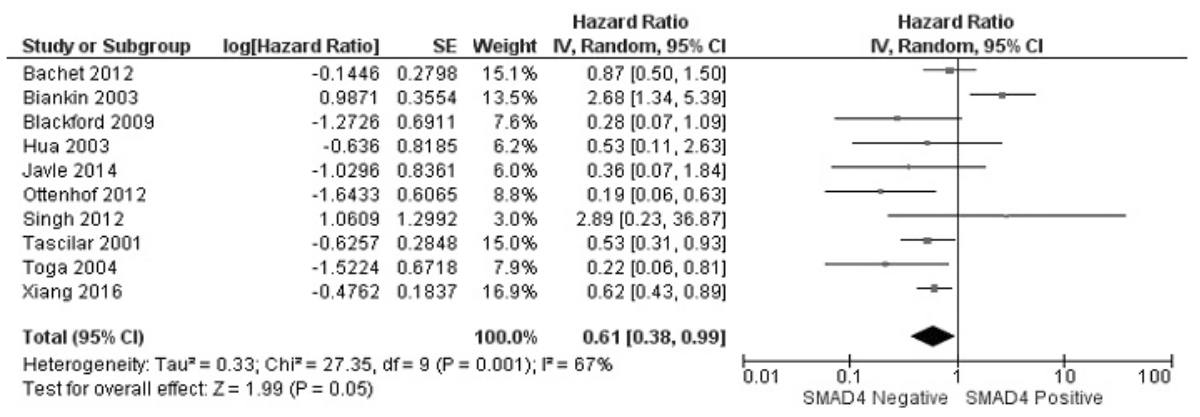

Figure 6: Forest plot for the association of SMAD4 protein expression with overall survival of patients with PDAC. 
Table 2: Quality assessment according to the Newcastle-Ottawa scale of the included studies

\begin{tabular}{lcccc}
\hline Author & Selection & Comparability & Exposure & Total score \\
\hline Bachet [13] & 3 & 2 & 3 & 8 \\
Biankin [38] & 3 & 2 & 3 & 8 \\
Javle [39] & 3 & 2 & 2 & 7 \\
Handra-Luca [12] & 2 & 2 & 3 & 7 \\
Hua [19] & 3 & 2 & 2 & 7 \\
Oshima [29] & 3 & 2 & 2 & 7 \\
Ottenhof [40] & 3 & 2 & 3 & 8 \\
Tang [41] & 2 & 2 & 2 & 6 \\
Tascilar [28] & 3 & 2 & 3 & 8 \\
Toga [42] & 2 & 2 & 3 & 7 \\
Xiang [43] & 2 & 2 & 3 & 7 \\
Zhang [44] & 2 & 2 & 2 & 6 \\
\hline
\end{tabular}

number of studies have reported the association between SMAD4 protein loss and lymphatic metastases [13, 19, 2627], however, the results were inconsistent [27-29]. Pooled OR suggested that the frequency of SMAD4 protein loss was not associated with lymphatic metastasis. TGFbeta/SMAD4-independent signaling pathway is activated due to SMAD4 loss [30]. TGF-beta activates the PI3K/Akt/ mTOR pathway and leads to increased migratory capacity and invasiveness during Epithelial-mesenchymal transition (EMT) which facilitates tumor progression and metastasis in PDAC. TGF-beta also suppresses PTEN through NFkappa B and enhanced cell motility and invasiveness [31].
Another activated downstream of TGF-beta/SMAD4independent signaling is STAT3 which has been proven to be an important regulator for PADC growth, invasion and angiogenesis [32-35]. On the other hand, SMAD4 serves as a tumor-suppressor and mediates cell cycle arrest as well as induced apoptosis in a SMAD4-dependent TGFbeta signaling pathway. The converse role of SMAD4 could be the reason that loss of SMAD4 is not associated with lymph node metastasis in PDAC. Recently Hingorani and colleagues used genetically engineered mouse model and found RUNX3 expression together with the DPC4/ $S M A D 4$ haploinsufficiency could inform metastasis status

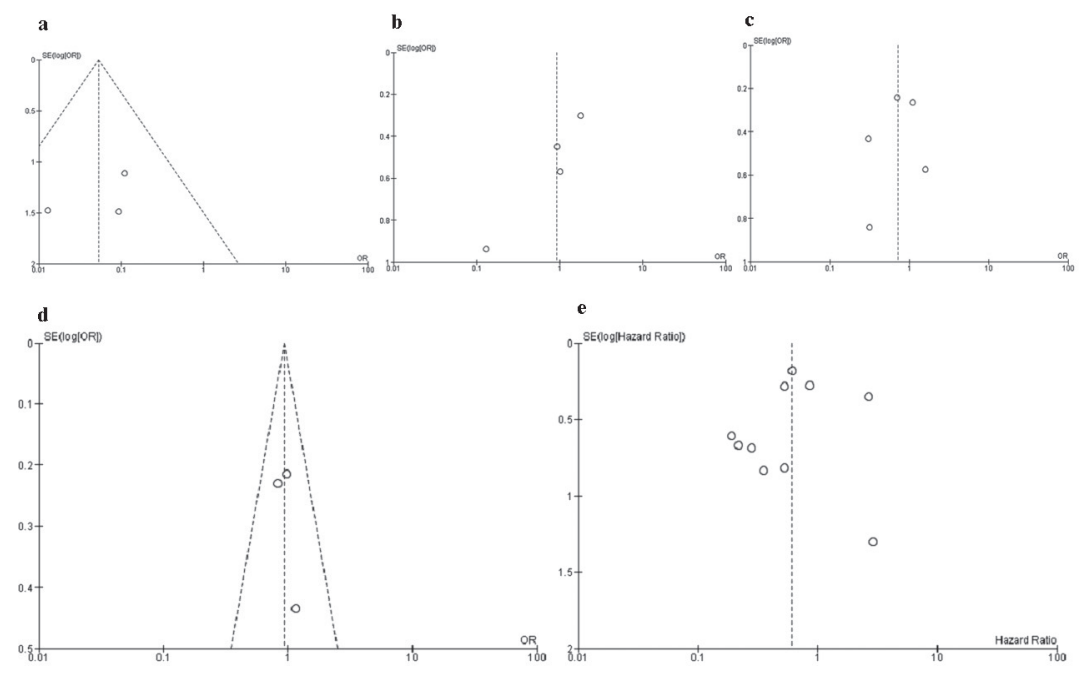

Figure 7: Funnel plot for publication bias. Each circle represents the weight of individual study. In $X$ axes, $\log (\mathrm{OR})=\mathrm{natural}$ logarithm of $\mathrm{OR}, \log (\mathrm{HR})=$ natural logarithm of $\mathrm{HR}, \mathrm{In} \mathrm{Y}$ axes, $\mathrm{SE}=$ standard error. a. SMAD4 protein expression in PDAC and nonmalignant pancreatic tissue; b. SMAD4 protein expression in different grade of PDAC; c. SMAD4 protein expression in different lymph node metastasis status; d. SMAD4 protein expression in different size of PDAC; e. the association of SMAD4 protein expression with overall survival of patients with PDAC. 
in PDAC [36]. More studies need to be finished in future for clinical application.

Although substantial progress has been made in understanding the pathogenesis of PDAC over last two decades, the prognosis is still poor. Multiple studies have been conducted showing inconsistencies of the association between SMAD4 expression status and prognosis in PDAC patients due to small samples [19, 29, 37-38]. In present study, the pooled data from ten studies indicated SMAD4 loss is significantly associated with prognosis in patients with PDAC. Finally our study selected all the published articles written in English and Chinese, did not include some relevant articles written in other languages or unpublished papers which may result in certain publication bias. Therefore, the result should be interpreted carefully.

In conclusion, SMAD4 is a biomarker for the diagnosis of PDAC. SMAD4 loss is significantly related with poor prognosis of patients with PDAC. SMAD4 loss is not associated with lymph node metastasis of PDAC.

\section{MATERIALS AND METHODS}

The meta-analysis was performed by using PRISMA checklist as a guide (Supplementary Checklist 1).

\section{Selection criteria and study search}

Systematic review of several databases was conducted in July 2016 with no lower limit set for date of publication. Following electronic databases were searched for relevant articles without any language restrictions: PubMed, Web of Science, Google scholar, and EMBASE. The keywords "SMAD4" or "DPC4" and "pancreatic cancer" or "pancreatic ductal adenocarcinoma" or pancreatic adenocarcinoma" were used for relative articles searching. There were 500 articles identified from PubMed, 452 articles from Web Science, 895 articles from EMBASE. 15,800 articles were identified from Google Scholar, first 200 of them were screened since the rest of them were not related to present study. A total of 2047 articles were initially identified by the search strategy, and 43 full-text articles were retrieved after screening. Forward and backward citation chasing of each selected article was performed in case they included another study of interest that had not been indentified. Studies were selected based on the following criteria: 1) The association between SMAD4 protein expression and the clinicopathological features of PDAC; 2) The association of SMAD4 protein expression and prognosis in patients with PDAC. SMAD4 protein expression was examined by immunochemistry. The following exclusion criteria were used: 1) the studies investigated the association between SMAD4 mRNA expression and clinicopathological significance 2) the studies utilized the same population or overlapping database, 3 ) the studies utilized cell lines or mice.

\section{Data extraction and study assessment}

Two reviewers (JW and XC) extracted data from selected studies independently. Any disagreement was discussed and reached a consensus for all issues. The following items were collected from each study: first author's name, year of publication, geographical location, age of patients, sample size, grades, size of the tumor, lymph node metastasis status, immunohistostaining, SMAD4 antibodies used, and HRs with 95\% CIs from multivariate analyses.

\section{Statistics analysis}

Odds ratios (OR) and hazard ratio with their 95\% confidence intervals were calculated. Heterogeneity among studies was estimated using the Cochran's Q statistic and $I^{2}$ tests. The $I^{2}$ statistic was used to examine the difference for between study variability due to heterogeneity rather than chance, with a range from 0 to 100 percent. A fixed effect model was used for $I^{2}<50 \%$, while a random effect model was used for $I^{2}>50 \%$. The analysis was performed to compare the frequency of SMAD4 protein expression between PDCA and nonmalignant prostate tissue. In addition, we evaluated the frequency of SMAD4 protein expression in different grades, different size of the tumor, and the correlation between SMAD4 expression and lymph node metastasis status, as well as the relationship between SMAD4 expression and prognosis in patients with PDCA. All $p$ values were two sided. Funnel plots were used for detection of publication bias. All analysis was performed with Review Manager 5.2 (Cochrane Collaboration, Software Update, Oxford, UK).

\section{ACKNOWLEDGMENTS}

This work was supported by National Natural Science Foundation of China (Grant No. 81374014), Zhejiang Provincial Science and Technology Projects (grants no. 2015C33264, 2017C33212 and 2017C33213), and Zhejiang Provincial Medical and Healthy Science and Technology Projects (Grants No. 2013KYA228 and 2016KYA180).

\section{CONFLICTS OF INTEREST}

The authors declare that they have no competing interests, and have no any financial disclosures.

\section{Authors' contribution}

JW, JL and KJ contributed substantially to the study and design, acquisition of data, and analysis and interpretation of data. JW and XC contributed substantially to the acquisition, analysis, interpretation of data and performed the statistical analysis. JW and JL have been involved in the drafting and critical revision of the article for important intellectual content. The corresponding author 
had full access to all data and the final responsibility for the decision to submit the article for publication. All authors read and approved the final manuscript.

\section{REFERENCES}

1. Siegel R, Ward E, Brawley O and Jemal A. Cancer statistics, 2011: the impact of eliminating socioeconomic and racial disparities on premature cancer deaths. CA Cancer J Clin. 2011; 61:212-236.

2. Shi G, Zhu L, Sun Y, Bettencourt R, Damsz B, Hruban RH and Konieczny SF. Loss of the acinar-restricted transcription factor Mist1 accelerates Kras-induced pancreatic intraepithelial neoplasia. Gastroenterology. 2009; 136:1368-1378.

3. Petrushnko W, Gundara JS, De Reuver PR, O'Grady G, Samra JS and Mittal A. Systematic review of peri-operative prognostic biomarkers in pancreatic ductal adenocarcinoma. HPB (Oxford). 2016; 18:652-663.

4. Thiagalingam S, Lengauer C, Leach FS, Schutte M, Hahn SA, Overhauser J, Willson JK, Markowitz S, Hamilton SR, Kern SE, Kinzler KW and Vogelstein B. Evaluation of candidate tumour suppressor genes on chromosome 18 in colorectal cancers. Nat Genet. 1996; 13:343-346.

5. Hahn SA, Schutte M, Hoque AT, Moskaluk CA, da Costa LT, Rozenblum E, Weinstein CL, Fischer A, Yeo CJ, Hruban RH and Kern SE. DPC4, a candidate tumor suppressor gene at human chromosome 18q21.1. Science. 1996; 271:350-353.

6. Singh P, Wig JD and Srinivasan R. The Smad family and its role in pancreatic cancer. Indian J Cancer. 2011; 48:351-360

7. Saiki Y and Horii A. Molecular pathology of pancreatic cancer. Pathol Int. 2014; 64:10-19.

8. Evan GI and Vousden KH. Proliferation, cell cycle and apoptosis in cancer. Nature. 2001; 411:342-348.

9. Siegel PM and Massague J. Cytostatic and apoptotic actions of TGF-beta in homeostasis and cancer. Nat Rev Cancer. 2003; 3:807-821.

10. David CJ, Huang YH, Chen M, Su J, Zou Y, Bardeesy $\mathrm{N}$, Iacobuzio-Donahue CA and Massague J. TGF-beta Tumor Suppression through a Lethal EMT. Cell. 2016; 164:1015-1030.

11. Massague J, Blain SW and Lo RS. TGFbeta signaling in growth control, cancer, and heritable disorders. Cell. 2000; 103:295-309.

12. Handra-Luca A, Hammel P, Sauvanet A, Ruszniewski P and Couvelard A. Tumoral epithelial and stromal expression of SMAD proteins in pancreatic ductal adenocarcinomas. J Hepatobiliary Pancreat Sci. 2013; 20:294-302.

13. Bachet JB, Marechal R, Demetter P, Bonnetain F, Couvelard A, Svrcek M, Bardier-Dupas A, Hammel P, Sauvanet A, Louvet C, Paye F, Rougier P, Penna C, Vaillant JC, Andre T, Closset J, et al. Contribution of CXCR4 and SMAD4 in predicting disease progression pattern and benefit from adjuvant chemotherapy in resected pancreatic adenocarcinoma. Ann Oncol. 2012; 23:2327-2335.

14. Voorneveld PW, Stache V, Jacobs RJ, Smolders E, Sitters AI, Liesker A, Korkmaz KS, Lam SM, De Miranda NF, Morreau H, Kodach LL and Hardwick JC. Reduced expression of bone morphogenetic protein receptor IA in pancreatic cancer is associated with a poor prognosis. $\mathrm{Br} \mathrm{J}$ Cancer. 2013; 109:1805-1812.

15. Crane CH, Varadhachary GR, Yordy JS, Staerkel GA, Javle MM, Safran H, Haque W, Hobbs BD, Krishnan S, Fleming JB, Das P, Lee JE, Abbruzzese JL and Wolff RA. Phase II trial of cetuximab, gemcitabine, and oxaliplatin followed by chemoradiation with cetuximab for locally advanced (T4) pancreatic adenocarcinoma: correlation of Smad4(Dpc4) immunostaining with pattern of disease progression. J Clin Oncol. 2011; 29:3037-3043.

16. DiGiuseppe JA, Hruban RH, Goodman SN, Polak M, van den Berg FM, Allison DC, Cameron JL and Offerhaus GJ. Overexpression of p53 protein in adenocarcinoma of the pancreas. Am J Clin Pathol. 1994; 101:684-688.

17. Apple SK, Hecht JR, Lewin DN, Jahromi SA, Grody WW and Nieberg RK. Immunohistochemical evaluation of K-ras, p53, and HER-2/neu expression in hyperplastic, dysplastic, and carcinomatous lesions of the pancreas: evidence for multistep carcinogenesis. Hum Pathol. 1999; 30:123-129.

18. Wilentz RE, Iacobuzio-Donahue CA, Argani P, McCarthy DM, Parsons JL, Yeo CJ, Kern SE and Hruban RH. Loss of expression of Dpc4 in pancreatic intraepithelial neoplasia: evidence that DPC4 inactivation occurs late in neoplastic progression. Cancer Res. 2000; 60:2002-2006.

19. Hua Z, Zhang YC, Hu XM and Jia ZG. Loss of DPC4 expression and its correlation with clinicopathological parameters in pancreatic carcinoma. World J Gastroenterol. 2003; 9:2764-2767.

20. Lecanda J, Ganapathy V, D'Aquino-Ardalan C, Evans B, Cadacio C, Ayala A and Gold LI. TGFbeta prevents proteasomal degradation of the cyclin-dependent kinase inhibitor p27kip1 for cell cycle arrest. Cell Cycle. 2009; 8:742-756

21. Bauer J, Sporn JC, Cabral J, Gomez J and Jung B. Effects of activin and TGFbeta on p21 in colon cancer. PLoS One. 2012; 7:e39381.

22. Tachibana I, Imoto M, Adjei PN, Gores GJ, Subramaniam M, Spelsberg TC and Urrutia R. Overexpression of the TGFbeta-regulated zinc finger encoding gene, TIEG, induces apoptosis in pancreatic epithelial cells. J Clin Invest. 1997; 99:2365-2374.

23. Duda DG, Sunamura M, Lefter LP, Furukawa T, Yokoyama $\mathrm{T}$, Yatsuoka $\mathrm{T}$, Abe $\mathrm{T}$, Inoue $\mathrm{H}$, Motoi F, Egawa S, Matsuno S and Horii A. Restoration of SMAD4 by gene therapy reverses the invasive phenotype in pancreatic adenocarcinoma cells. Oncogene. 2003; 22:6857-6864.

24. Yasutome M, Gunn J and Korc M. Restoration of Smad4 in $\mathrm{BxPC} 3$ pancreatic cancer cells attenuates proliferation 
without altering angiogenesis. Clin Exp Metastasis. 2005; 22:461-473.

25. Shen W, Tao GQ, Li DC, Zhu XG, Bai X and Cai B. Inhibition of pancreatic carcinoma cell growth in vitro by DPC4 gene transfection. World J Gastroenterol. 2008; 14:6254-6260.

26. Taniguchi $\mathrm{C}$ and Maitra A. It's a SMAD/SMAD World. Cell. 2015; 161:1245-1246.

27. Boone BA, Sabbaghian S, Zenati M, Marsh JW, Moser AJ, Zureikat AH, Singhi AD, Zeh HJ, 3rd and Krasinskas AM. Loss of SMAD4 staining in pre-operative cell blocks is associated with distant metastases following pancreaticoduodenectomy with venous resection for pancreatic cancer. J Surg Oncol. 2014; 110:171-175.

28. Tascilar M, Skinner HG, Rosty C, Sohn T, Wilentz RE, Offerhaus GJ, Adsay V, Abrams RA, Cameron JL, Kern SE, Yeo CJ, Hruban RH and Goggins M. The SMAD4 protein and prognosis of pancreatic ductal adenocarcinoma. Clin Cancer Res. 2001; 7:4115-4121.

29. Oshima M, Okano K, Muraki S, Haba R, Maeba T, Suzuki $\mathrm{Y}$ and Yachida S. Immunohistochemically detected expression of 3 major genes (CDKN2A/p16, TP53, and SMAD4/DPC4) strongly predicts survival in patients with resectable pancreatic cancer. Ann Surg. 2013; 258:336-346.

30. Derynck R, Jarrett JA, Chen EY, Eaton DH, Bell JR, Assoian RK, Roberts AB, Sporn MB and Goeddel DV. Human transforming growth factor-beta complementary DNA sequence and expression in normal and transformed cells. Nature. 1985; 316:701-705.

31. Chow JY, Quach KT, Cabrera BL, Cabral JA, Beck SE and Carethers JM. RAS/ERK modulates TGFbeta-regulated PTEN expression in human pancreatic adenocarcinoma cells. Carcinogenesis. 2007; 28:2321-2327.

32. Li H, Huang C, Huang K, Wu W, Jiang T, Cao J, Feng Z and Qiu Z. STAT3 knockdown reduces pancreatic cancer cell invasiveness and matrix metalloproteinase-7 expression in nude mice. PLoS One. 2011; 6:e25941.

33. Yang G, Huang C, Cao J, Huang KJ, Jiang T and Qiu ZJ. Lentivirus-mediated shRNA interference targeting STAT3 inhibits human pancreatic cancer cell invasion. World J Gastroenterol. 2009; 15:3757-3766.

34. Huang C, Jiang T, Zhu L, Liu J, Cao J, Huang KJ and Qiu ZJ. STAT3-targeting RNA interference inhibits pancreatic cancer angiogenesis in vitro and in vivo. Int J Oncol. 2011; 38:1637-1644.
35. Zhao S, Venkatasubbarao K, Lazor JW, Sperry J, Jin C, Cao L and Freeman JW. Inhibition of STAT3 Tyr705 phosphorylation by Smad4 suppresses transforming growth factor beta-mediated invasion and metastasis in pancreatic cancer cells. Cancer Res. 2008; 68:4221-4228.

36. Whittle MC, Izeradjene K, Rani PG, Feng L, Carlson MA, DelGiorno KE, Wood LD, Goggins M, Hruban RH, Chang AE, Calses P, Thorsen SM and Hingorani SR. RUNX3 Controls a Metastatic Switch in Pancreatic Ductal Adenocarcinoma. Cell. 2015; 161:1345-1360.

37. Khorana AA, Hu YC, Ryan CK, Komorowski RA, Hostetter $\mathrm{G}$ and Ahrendt SA. Vascular endothelial growth factor and DPC4 predict adjuvant therapy outcomes in resected pancreatic cancer. J Gastrointest Surg. 2005; 9:903-911.

38. Biankin AV, Morey AL, Lee CS, Kench JG, Biankin SA, Hook HC, Head DR, Hugh TB, Sutherland RL and Henshall SM. DPC4/Smad4 expression and outcome in pancreatic ductal adenocarcinoma. J Clin Oncol. 2002; 20:4531-4542.

39. Javle M, Li Y, Tan D, Dong X, Chang P, Kar S and Li D. Biomarkers of TGF-beta signaling pathway and prognosis of pancreatic cancer. PLoS One. 2014; 9:e85942.

40. Ottenhof NA, Morsink FH, Ten Kate F, van Noorden CJ and Offerhaus GJ. Multivariate analysis of immunohistochemical evaluation of protein expression in pancreatic ductal adenocarcinoma reveals prognostic significance for persistent Smad4 expression only. Cell Oncol (Dordr). 2012; 35:119-126.

41. Tang ZH, Zou SQ, Hao YH, Wang BJ, Yang XP, Chen QQ and Qiu FZ. The relationship between loss expression of DPC4/Smad4 gene and carcinogenesis of pancreatobiliary carcinoma. Hepatobiliary Pancreat Dis Int. 2002; 1:624-629.

42. Toga T, Nio Y, Hashimoto K, Higami T and Maruyama $\mathrm{R}$. The dissociated expression of protein and messenger RNA of DPC4 in human invasive ductal carcinoma of the pancreas and their implication for patient outcome. Anticancer Res. 2004; 24:1173-1178.

43. Xiang JF, Wang WQ, Liu L, Xu HX, Wu CT, Yang JX, Qi ZH, Wang YQ, Xu J, Liu C, Long J, Ni QX, Li M and Yu XJ. Mutant p53 determines pancreatic cancer poor prognosis to pancreatectomy through upregulation of cavin- 1 in patients with preoperative serum CA19-9 $>/=$ 1,000 U/mL. Sci Rep. 2016; 6:19222.

44. Zhang S, Xiang, T., Li, Y. Expression and significance of gene p16, p53 and Smad4 in pancreatic carcinoma. Acta Academiae Medicinae Qingdao Universitatis. 2006; 42:2-4. 